\title{
Total Synthesis of Asparenydiol by Two Sonogashira Cross-Coupling Reactions Promoted by Supported Pd and Cu Catalysts
}

\author{
Gianluca Casottia ${ }^{\text {(i) }}$ \\ Graziano Fusinia \\ Matteo Ferreria \\ Luca Fidia Pardinia \\ Claudio Evangelisti*b \\ Gaetano Angelici*a (D) \\ Adriano Carpita ${ }^{a}$ \\ ${ }^{a}$ Department of Chemistry and Industrial Chemistry, University \\ of Pisa, Via G. Moruzzi 13, 56124 Pisa, Italy \\ gaetano.angelici@unipi.it \\ ${ }^{\mathrm{b}}$ CNR, Istituto di Chimica dei Composti Organometallici \\ (ICCOM), Via G. Moruzzi 1, 56124, Pisa, Italy \\ claudio.evangelisti@cnr.it
}

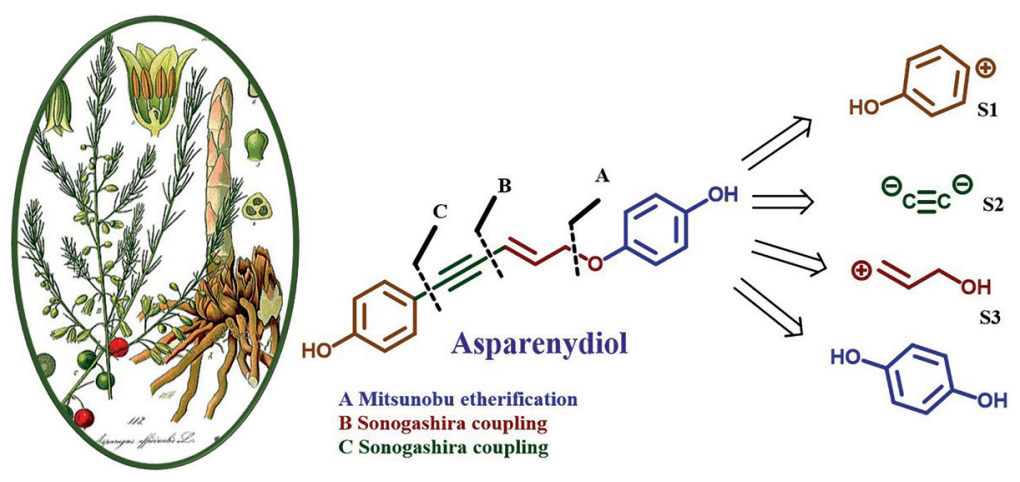

In loving memory of Prof. Adriano Carpita
Received: 16.01.2020

Accepted after revision: 18.02 .2020

Published online: 05.03 .2020

DOI: 10.1055/s-0039-1690852; Art ID: ss-2020-t0034-op

Abstract Asparenydiol, which is an important natural compound with potential pharmacological activities, was synthesized through two Sonogashira cross-coupling reactions catalyzed by supported Pd and Cu catalysts and by a Mitsunobu etherification. The optimization of the Sonogashira couplings allowed the use of catalysts supported on different matrices with good results in terms of catalytic efficiency and yields.

Key words Asparenydiol, Sonogashira cross-coupling, Mitsunobu etherification, total synthesis, solid-supported palladium catalyst

Asparenydiol is an acetylenic compound that was isolated for the first time from Asparagus officinalis by Terada and co-workers in 1995, ${ }^{1}$ and afterwards found in Asparagus cochinchinensis ${ }^{2}$ and also in Asparagus racemosus. ${ }^{3}$ These plants have long been known for their use in ethnomedicine. Notably, A. cochinchinensis was reported to be used for treating fever, cough, kidney diseases, and benign breast tumors in China, and A. racemosus was used to treat gastric ulcers, diabetes and to improve immunity in India. Asparenydiol was found to exhibit moderate bioactivity on some tumoral cell lines (KB, Col-2, LNCaP, Lu-1 and HUVEC), with $\mathrm{IC}_{50}$ values between 4 and $20 \mu \mathrm{g} / \mathrm{mL}^{4}{ }^{4}$ Despite the potential pharmacological applications, the difficult and low-yielding process of extraction ( $2 \mathrm{mg}$ of Asparenydiol from $5 \mathrm{~kg}$ of roots) limits an extensive screening of its properties. Moreover, to our knowledge, there are still no examples of synthetic pathways that are suitable for largescale production of Asparenydiol.
After careful retrosynthetic analysis, we envisioned the possibility of formally applying three main disconnections, as shown in Scheme 1, which could allow the use of commercially available building blocks or easy to synthesize intermediates. Disconnection A could synthetically correspond to a formal etherification, while $\mathbf{B}$ and $\mathbf{C}$ disconnections suggest the possibility of building the Asparenydiol core around its triple bond, using a formal double ethynyl donor synthon. More specifically, in Scheme 2, the chosen building blocks are shown based on the disconnections proposed. For disconnection A, we planned an etherification between a phenol and an allylic alcohol through a Mitsunobu reaction, which allows neutral conditions and it is compatible with sensitive allylic substrates that are at risk of regioisomerization. ${ }^{5,6}$

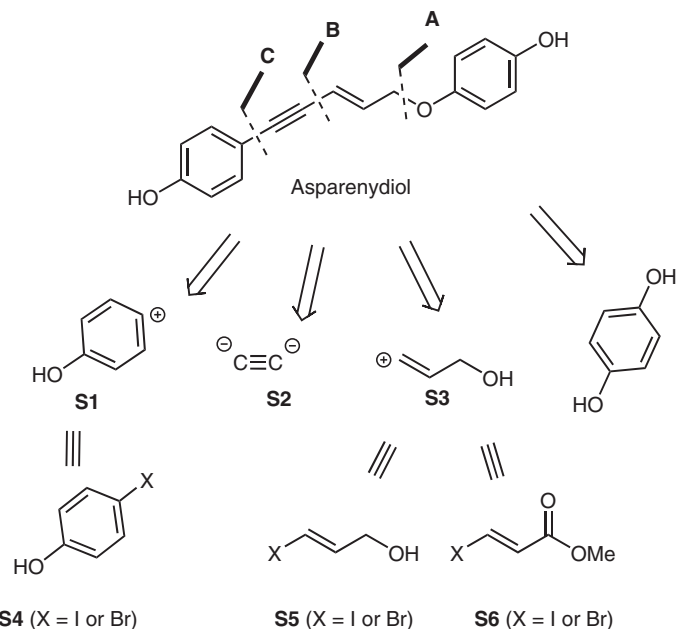

Scheme 1 General retrosynthetic analysis for Asparenydiol 
To avoid oligomer formation and homoetherification, the initial protection of one of the hydroxyl groups of hydroquinone and subsequent intermediates is necessary. Among the most common protecting groups for phenol protection, we chose to use tert-butyldimethylsilyl ether, for its chemical stability and the orthogonality compared to trimethylsilyl ether, necessary for the synthesis of intermediate compound 3 . We also considered the possibility of using a two-step Williamson etherification, in which the allylic alcohol is previously transformed into the corresponding chloride, bromide, mesylate or tosylate, followed by nucleophilic substitution of the phenol under basic conditions. Preliminary results, however, suggested that, in this case, the Mitsunobu reaction is more reliable. For disconnections $\mathbf{B}$ and $\mathbf{C}$, we envisioned the use of the Sonogashira reaction, ${ }^{7}$ that, in its original version, promotes the alkynylation of aryl or alkenyl halides, co-catalyzed by Pd and $\mathrm{Cu}(\mathrm{I})$, in the presence of a base. ${ }^{8}$

Today, the Sonogashira reaction is commonly performed under homogeneous catalysis conditions; ${ }^{9}$ it does not require preformed organometallic acceptor species in stoichiometric amounts, as in the case of Negishi cross-coupling reactions, ${ }^{10}$ which is also used for the synthesis of natural compounds. ${ }^{11}$ For larger-scale and greener applications of the Sonogashira reaction, several methods have been developed, including copper-free reactions, solvent-less reac- tions, and, notably, Pd-based supported catalysts such as $\mathrm{Pd} / \mathrm{C}^{12}$ Depending on the order of disconnection between $\mathbf{B}$ and $\mathbf{C}$, the structure of the intermediates could change (12 or 4 ), even though the building blocks to obtain $\mathbf{8}$ are essentially the same; 4-tert-butyldimethylsilyl-1-iodobenzene (2), (E)-3-bromoacrylate (7) and trimethylsilylacetylene (13). Nevertheless, there is only one example of the synthesis of 12, through a cross-coupling reaction in $\mathrm{Pd} / \mathrm{Cu}$ homogeneous catalysis, reported by Garrais et al. in 2009, ${ }^{13}$ whereas we had extensive experience in the preparation of intermediate $4 .{ }^{14}$ In particular, disconnection B would correspond to a Sonogashira reaction between terminal alkyne 4 and an (E)-1-halo-3-hydroxy-1-propene to yield 8, with both nascent hydroxy groups protected. Even though there are several examples of the latter substrate being used successfully in homogeneous catalysis at room temperature, ${ }^{15-18}$ there are none in heterogeneous catalysis, probably due to the instability at higher temperatures, or to the possibility to form oxidative addition complexes with palladium. Therefore, we opted to use methyl (E)-3-bromoacrylate (7), which can be easily reduced afterwards with DIBALH at low temperature without regio-isomerization, as reported by several groups. ${ }^{19,13}$ For example, in 2000, Takeuchi et al. proposed a stereoselective synthesis of 2-alken-4-ynoates through Sonogashira reaction between arylalkynes and vinyl iodides, ${ }^{20}$ which looked promising for our purpose. We

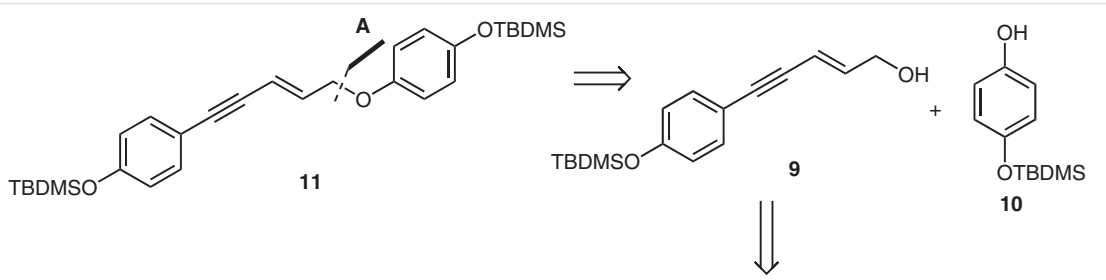<smiles>[B]C(C)(C)C=CC(=O)OC</smiles>

12
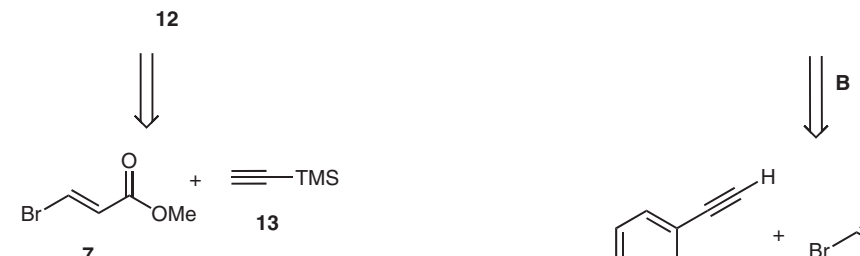<smiles>COC(=O)/C=C/Br</smiles>

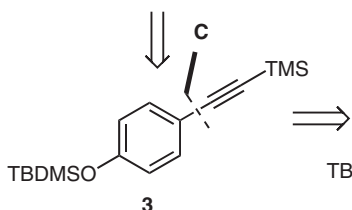

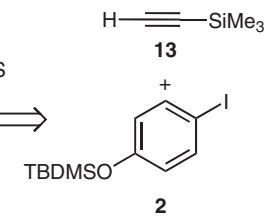

Scheme 2 Retrosynthetic analysis with the proposed building blocks 
also considered alternatives such as an oxidative alkynylation catalyzed by palladium, as proposed by Nishimura et al. ${ }^{21}$ and a cross-coupling between $(E)$-3-iodoacrylate and phenylacetylene promoted only by $\mathrm{Cu}(\mathrm{I})$, proposed by Bates et al. ${ }^{22}$ However, for these two methods, the catalyst loadings and the temperatures were too high for our system. Interestingly, Ranu et al. studied the reaction between $(E)$ 1,2-diiodostyrenes and acrylates catalyzed by palladium nanoparticles in homogeneous catalysis ${ }^{23}$ and, afterwards, they minimized the palladium contamination by using palladium supported on hydroxyapatite, ${ }^{24}$ and using a low catalyst loading $\left(4.5 \times 10^{-3} \mathrm{~mol} \%\right.$ of Pd). Unfortunately, this method is not suitable in our case, because reaction conditions require potassium carbonate and high temperature, which could potentially lead to deprotection of the phenol needed in the next step of etherification; furthermore, $(E)$ 1,2-diiodostyrenes are not directly available.

The first step of the Asparenydiol (15) synthesis was the protection of 4-iodo-phenol with TBDMSCl, using a slightly modified version of the reported procedure, ${ }^{25}$ giving compound 2 in quantitative yield. For the first Sonogashira cross-coupling, we tested a range of commercially available supported palladium catalysts [Pd EnCat ${ }^{\mathrm{TM}} 40$, FibreCat 1007, $\mathrm{Pd}\left(\mathrm{PPh}_{3}\right)_{4} \mathrm{PS}$, and $\left.\mathrm{PdCl}_{2}\left(\mathrm{PPh}_{3}\right)_{2} / \mathrm{PS}\right]$ and two polyvinylpyridine(PVPy)-supported catalysts recently developed by our research group ( $\mathrm{Cu} / \mathrm{PVPy}$ and $\mathrm{Pd}-\mathrm{Cu} / \mathrm{PVPy}){ }^{26,27}$ The ability of the PVPy resin to promote M-H-type alkenylations, ensuring also very low metal leaching, was previously reported. . $^{28,29}$

The reaction conditions were initially optimized using Pd EnCat ${ }^{\mathrm{TM}} 40$ as a catalyst (Table 1), because this was already successfully tested for the synthesis of some natural compounds. ${ }^{11,30}$

We initially tried to perform the reaction in the absence of copper (Table 1, entry 1 ), however, although the starting material disappeared after $3.5 \mathrm{~h}$, many different side-products were formed, and a low yield of the desired product was obtained. The reaction was therefore tested under more classical Sonogashira conditions with a 2:1 ratio between palladium and copper, but with reduced catalyst loading ( $0.5 \mathrm{~mol} \%$ of Pd; entries $2-4)$; also in this case, after $5 \mathrm{~h}$, many collateral reactions took place. In an attempt to minimize the formation of by-products, the reaction was performed at $70^{\circ} \mathrm{C}$ (entry 5), but a low conversion was obtained, showing that the supported catalysis lost efficiency below certain temperatures. A decrease of the amount of copper, instead, led to the formation of lower amounts of by-products, albeit with longer reaction time $(9 \mathrm{~h})$, and allowed the isolation of the product with $40 \%$ yield (entries $6-8$ ). The reaction was also tested in the presence of two different solvents, DMF and toluene (entries 9-12), but irrespective of the polarity of the solvent, lower conversions were obtained. These results suggest that the collateral reactions are dependent on the amount of copper iodide that is soluble in pyrrolidine. Therefore, as the homogeneous ca-
Table 1 Cross-Coupling Reaction Optimization with 2 and 13

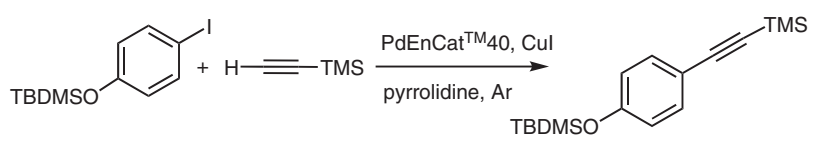

13

3

Entry PdEnCat ${ }^{\mathrm{TM}} 40$ Cul Temp. Time Conv. Yield (\%) $\begin{array}{llll}(\mathrm{Pd} \mathrm{mol} \%) & (\mathrm{Cu} \mathrm{mol} \%) & \left({ }^{\circ} \mathrm{C}\right) & \text { (h) } \quad(\%)^{\mathrm{d}}\end{array}$

\begin{tabular}{lllllll}
\hline $1^{\mathrm{a}}$ & 1 & - & 95 & 3.5 & 96 & 28 \\
\hline $2^{\mathrm{a}}$ & 0.5 & 1 & 90 & 1 & 73 & - \\
$3^{\mathrm{a}}$ & & & & 3 & 84 & - \\
$4^{\mathrm{a}}$ & & & & 5 & 95 & - \\
\hline $5^{\mathrm{a}}$ & 0.5 & 1 & 70 & 2.5 & 44 & - \\
\hline $6^{\mathrm{a}}$ & 0.5 & 0.25 & 90 & 1 & 53 & - \\
$7^{\mathrm{a}}$ & & & & 5 & 88 & - \\
$8^{\mathrm{a}}$ & & & & 9 & $>99$ & 40 \\
\hline $9^{\mathrm{b}}$ & 0.5 & 0.25 & 90 & 1 & 5 & - \\
$10^{\mathrm{b}}$ & & & & 8 & 51 & - \\
\hline $11^{\mathrm{c}}$ & 0.5 & 0.25 & 90 & 1 & $<5$ & - \\
$12^{\mathrm{c}}$ & & & & 16 & 25 & -
\end{tabular}

a Reaction conditions: 2 ( 2.0 mmol), 13 (1.5 equiv), pyrrolidine (3.0 equiv), Pd EnCat ${ }^{\mathrm{TM}} 40$, Cul, argon.

b Reaction conditions: 2 ( $2.0 \mathrm{mmol}), 13$ (1.5 equiv), pyrrolidine (2.0 equiv), DMF (3 mL), Pd EnCat ${ }^{\mathrm{TM}} 40$, Cul, argon.

' Reaction conditions: 2 (2.0 mmol), 13 (1.5 equiv), pyrrolidine (2 equiv), toluene (3 mL), Pd EnCatTM40, Cul, argon.

${ }^{d}$ Apparent conversion based on the disappearance of precursor $\mathbf{2}$, calculated by GC analysis as percentage ratio between the sum of the areas of the product and sub-products and whole addition of the areas.

e Isolated yield of 3 after flash chromatography.

talysis of copper could be more efficient than the supported palladium catalysis, we tested a previously described supported copper species $\mathrm{Cu} / \mathrm{PVPy}$. As detected by X-ray absorption fine structure spectroscopy and high-resolution transmission electron microscopy, this catalyst contains $\mathrm{Cu}(\mathrm{I})$ nanoparticles (mean diameter of $3.3 \mathrm{~nm}$ ) in form of copper oxide $\left(\mathrm{Cu}_{2} \mathrm{O}\right) \cdot{ }^{27}$ Reaction rate and isolated yield (53\%) significantly increased in this case (Table 2, entries 1 and 2), although it was still not satisfactory.

Consequently, other palladium supported catalysts were tested under the latter conditions, with the best results being obtained using $\mathrm{PdCl}_{2}\left(\mathrm{PPh}_{3}\right)_{2} / \mathrm{PS}$ with a yield of $70 \%$ after $1.5 \mathrm{~h}$ (Table 2, entry 7 ). An improvement of the isolated yield ( $81 \%)$ was obtained by increasing the reaction time to $3.5 \mathrm{~h}$, even when the amount of catalyst loading was reduced to $0.25 \mathrm{~mol} \%$ of Pd, as shown in Table 2, entry 12 . For a direct comparison of efficiency between the supported co-catalyst and its homogeneous version, the reaction using $\mathrm{PdCl}_{2}\left(\mathrm{PPh}_{3}\right)_{2}$ and Cul was tested (entry 13). As expected, the reaction run with homogeneous catalysis led to better results in terms of yield $(93 \%)$, temperature $\left(20^{\circ} \mathrm{C}\right)$, and reaction time. However, the opportunity to carry out crosscoupling reactions with supported catalysis can offer several advantages with respect to the development of sustainable 
Table 2 Screening of Pd Supported Catalysts under the Optimized Conditions

\begin{tabular}{|c|c|c|c|c|c|}
\hline & 13 & & & 3 & \\
\hline Entry & 'Pd' (mol\% Pd) & ‘Cu' (mol\% Cu) & $t(\mathrm{~h})$ & $\begin{array}{l}\text { Conv. } \\
(\%)^{c}\end{array}$ & $\begin{array}{l}\text { Yield } \\
(\%)^{d}\end{array}$ \\
\hline $1^{\mathrm{a}}$ & PdEnCat $^{\mathrm{TM}} 40(0.5)$ & Cu/PVPy (0.25) & 1 & 85 & \\
\hline $2^{\mathrm{a}}$ & & & 2 & $>99$ & 53 \\
\hline $3^{\mathrm{a}}$ & Pd FibreCat $\circledast 1007(0.5)$ & $\mathrm{Cu} / \mathrm{PVPy}(0.25)$ & 1 & 67 & \\
\hline $4^{\mathrm{a}}$ & & & 2 & 80 & \\
\hline $5^{\mathrm{a}}$ & & & 4 & 95 & - \\
\hline $6^{a}$ & $\mathrm{PdCl}_{2}\left(\mathrm{PPh}_{3}\right)_{2} / \mathrm{PS}(0.5)$ & $\mathrm{Cu} / \mathrm{PVPy}(0.25)$ & 1 & 89 & \\
\hline $7^{\mathrm{a}}$ & & & 1.5 & $>99$ & 70 \\
\hline $8^{\mathrm{a}}$ & Pd-Cu/PVPy (0.5-0.25) & & 1 & 29 & \\
\hline $9^{a}$ & & & 5 & 51 & \\
\hline $10^{\mathrm{a}}$ & $\mathrm{PdCl}_{2}\left(\mathrm{PPh}_{3}\right)_{2} / \mathrm{PS}(0.25)$ & Cu/PVPy (0.125) & 1 & 54 & \\
\hline $11^{\mathrm{a}}$ & & & 2 & 89 & \\
\hline $12^{\mathrm{a}}$ & & & 3.5 & $>99$ & 81 \\
\hline $13^{b}$ & $\mathrm{PdCl}_{2}\left(\mathrm{PPh}_{3}\right)_{2}(0.25)$ & Cul (0.125) & 2 & & 93 \\
\hline \multicolumn{6}{|c|}{ 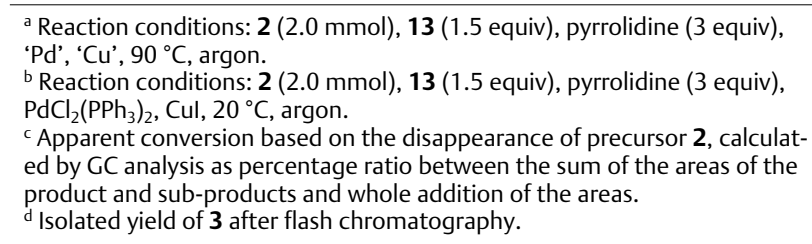 } \\
\hline
\end{tabular}

synthetic approaches. Indeed, although the reaction mechanisms are still under debate and conclusive proof that the reactions can actually take place at the metal surface with a real 'heterogeneous' mechanism is still lacking, ${ }^{31}$ the use of supported catalysts remain a valid alternative to avoid contamination with heavy metals as well as facilitating the reaction workup in compounds of pharmacological interest.

For the selective deprotection of the trimethylsilyl acetylenic moiety, a reported method ${ }^{14}$ using silver nitrate (10 mol\%) was applied, as shown in Scheme 3, with a yield of $97 \%$.

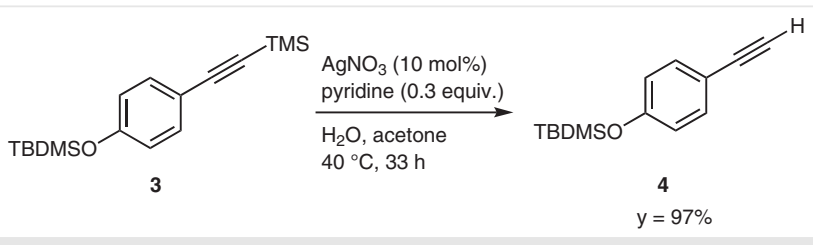

Scheme 3 Selective deprotection of $\mathbf{3}$

Methyl (E)-3-bromoacrylate (7), which was necessary for the next cross-coupling reaction, was prepared through a known two-step synthesis. ${ }^{32}$ For the second Sonogashira cross-coupling, the reaction was previously tested on phenylacetylene (14), to establish optimal reaction conditions. However, regardless of the catalyst used, when pyrrolidine was added as a base, an exothermic reaction was observed, forming (E)-methyl 3-(pyrrolidin-1-yl)acrylate, as the major product. Therefore, it was necessary to test several sterically hindered tertiary amines, as bases, using $\mathrm{PdCl}_{2}\left(\mathrm{PPh}_{3}\right)_{2} / \mathrm{PS}$ as a catalyst, under the same conditions described above. $\mathrm{N}$-Methyl- and $\mathrm{N}$-butyl-pyrrolidine did not bring any improvement, whereas DABCO (in 4:1 DMF/ $\mathrm{H}_{2} \mathrm{O}$ solution) and triethylamine lead mainly to the homodimerization of phenylacetylene. The best results were obtained using 2,2,6,6-tetramethylpiperidine as a base, as shown in Table 3. The use of Pd-Cu/PVPy was particularly effective, with a yield of $62 \%$ in only $3.5 \mathrm{~h}$; therefore, these conditions were used to optimize the next step.

Table 3 Cross-Coupling Reaction Optimization with 14 and 7

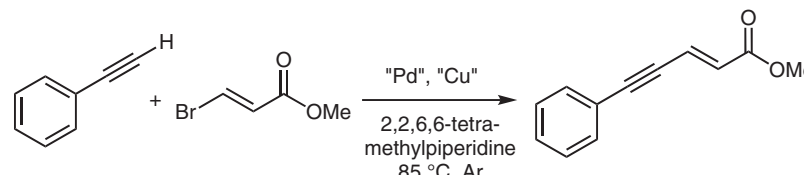

$14 \quad 75^{\circ} \mathrm{C}, \mathrm{Ar} \quad 20$

\begin{tabular}{lccclcc}
\hline Entry & 'Pd' (mol\% Pd) & $\begin{array}{c}\text { ‘Cu' } \\
\text { (mol\% Cu) }\end{array}$ & $t$ (h) & $\begin{array}{l}2,2,6,6 \text {-tetramehyl- } \\
\text { piperidine (equiv) }\end{array}$ & $\begin{array}{l}\text { Yield } \\
(\%)^{\mathrm{b}}\end{array}$ \\
\hline 1 & $\mathrm{PdCl}_{2}\left(\mathrm{PPh}_{3}\right)_{2} / \mathrm{PS}(2)$ & $\mathrm{Cul}(4)$ & 22 & 15 & 52 \\
2 & $\mathrm{PdCl}_{2}\left(\mathrm{PPh}_{3}\right)_{2} / \mathrm{PS}(2)$ & $\mathrm{Cul}(4)$ & 22 & 6 & 35 \\
3 & $\mathrm{Pd}-\mathrm{Cu} / \mathrm{PVPy}(2-1)$ & 3.5 & 6 & 62 \\
4 & $\mathrm{Pd}-\mathrm{Cu} / \mathrm{PVPy}(0.5-0.25)$ & 3.5 & 6 & 40 \\
\hline
\end{tabular}

a Reaction conditions: 14 (1.0 mmol), 7 (1.5 equiv), base, 'Pd', 'Cu', $85^{\circ} \mathrm{C}$, argon.

$\mathrm{b}$ Isolated yield of $\mathbf{2 0}$ after flash chromatography.

As shown in Table 4, Pd-Cu/PVPy was a good catalyst for the synthesis of $\mathbf{8}$, even with a loading of $0.5 \mathrm{~mol} \%$ in Pd and $0.25 \mathrm{~mol} \%$ in $\mathrm{Cu}$ (entries 1 and 2). These results were unfortunately not comparable with the excellent yield obtained with homogeneous catalysis (entry 5) and the choice of supported catalyst is a compromise with the need to develop greener methods.

It is worth noting that, in the first Sonogashira step, the use of the two separated supported catalysts, $\mathrm{PdCl}_{2}\left(\mathrm{PPh}_{3}\right)_{2} / \mathrm{PS}$ and $\mathrm{Cu} / \mathrm{PVPy}$ (Table 2, entry 11), was highly effective, whereas for the synthesis of $\mathbf{8}$ it was not reactive enough (Table 4, entry 4). For the second Sonogashira step, it was necessary to use the supported co-catalyst Pd-Cu/PVPy (Table 4, entries 1 and 2). Rationalization of this different behavior is not obvious but can be ascribed to the different reactivity of the two systems, rather than to instability of reagents or product, because, in both cases, the corresponding halides could be recovered. Pd-Cu/PVPy is not a simple mixture of segregated $\mathrm{Pd}$ and $\mathrm{Cu}$ nanoparticles dispersed on PVPy. ${ }^{26}$ In this catalyst, an oxidized $\mathrm{Cu}(\mathrm{II})$ phase is 
Table 4 Cross-Coupling Reaction Optimization with $\mathbf{4}$ and $\mathbf{7}$

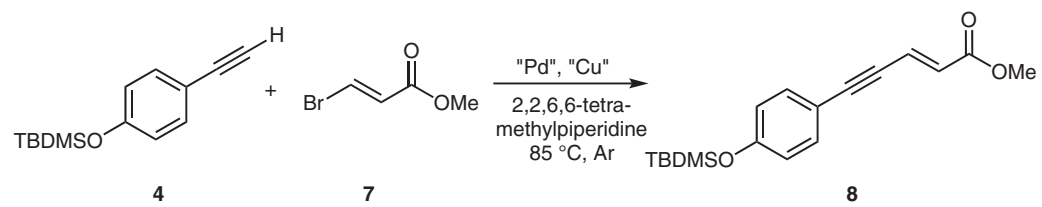

\begin{tabular}{llllll}
\hline Entry & 'Pd' (mol\% Pd) & 'Cu' (mol\% Cu) & $t(\mathrm{~h})$ & $2,2,6,6$-tetramehylpiperidine (equiv) & Yield (\%) $^{\mathrm{d}}$ \\
\hline $1^{\mathrm{a}}$ & $\mathrm{Pd}-\mathrm{Cu} / \mathrm{PVPy}(2-1)$ & & 3.5 & 6 & 62 \\
$2^{\mathrm{a}}$ & $\mathrm{Pd}-\mathrm{Cu} / \mathrm{PVPy}(0.5-0.25)$ & 3.5 & 6 & 57 \\
$3^{\mathrm{b}}$ & $\mathrm{PdCl}_{2}\left(\mathrm{PPh}_{3}\right)_{2} / \mathrm{PS}(2)$ & - & 48 & 3 & 40 \\
$4^{\mathrm{c}}$ & $\mathrm{PdCl}_{2}\left(\mathrm{PPh}_{3}\right)_{2} / \mathrm{PS}(0.5)$ & $\mathrm{Cu} / \mathrm{PVPy}(0.25)$ & 7 & 3 & - \\
$5^{\mathrm{a}}$ & $\mathrm{PdCl}_{2}\left(\mathrm{PPh}_{3}\right)_{2}(0.5)$ & $\mathrm{Cul}(0.25)$ & 4 & $\mathrm{Et}_{3} \mathrm{~N}(6$ equiv) & 92 \\
\hline
\end{tabular}

a Reaction conditions: 4 (2.0 mmol), 7 (1.5 equiv), base, 'Pd', 'Cu', $85^{\circ} \mathrm{C}$, argon.

${ }^{b}$ Reaction temperature was increased to $95^{\circ} \mathrm{C}$ after $2 \mathrm{~h}$.

c Reaction temperature was increased to $100{ }^{\circ} \mathrm{C}$ after $3 \mathrm{~h}$. After $7 \mathrm{~h}$, the reaction reached only $10 \%$ of apparent conversion. The product was not isolated.

${ }^{\mathrm{d}}$ Isolated yield of 8 after flash chromatography.

present, forming thin and incomplete shells around the Pd-rich cores. The specific interaction between Pd and $\mathrm{Cu}$ at the nanoparticle surface was demonstrated to be responsible of the observed marked increase in catalytic efficiency in Sonogashira-like reactions. Afterwards, the obtained ester 8 was reduced to the corresponding allylic alcohol 9 using DIBALH as reducing agent, at low temperature, with an isolated yield of $90 \%$ (Scheme 4 ). Although alkynes can undergo hydroalumination reactions, ${ }^{20,33,34}$ maintaining a low temperature, especially during the addition of DIBALH, en- ables selective reduction of the ester moiety. Moreover, when only three equivalents of DIBALH were used, the reaction was compatible with the presence of the TBDMS protecting group; application of an excess of the reducing agent led to partial deprotection of the phenol.

For the next step, the monosilylation of hydroquinone was achieved using a slightly modified reported method, ${ }^{35,36}$ with a yield of $\mathbf{1 0}$ of $74 \%$ (see the experimental section). Mitsunobu etherification between $\mathbf{9}$ and 10 was performed under classical conditions, ${ }^{37,38}$ using diethyl azodi-

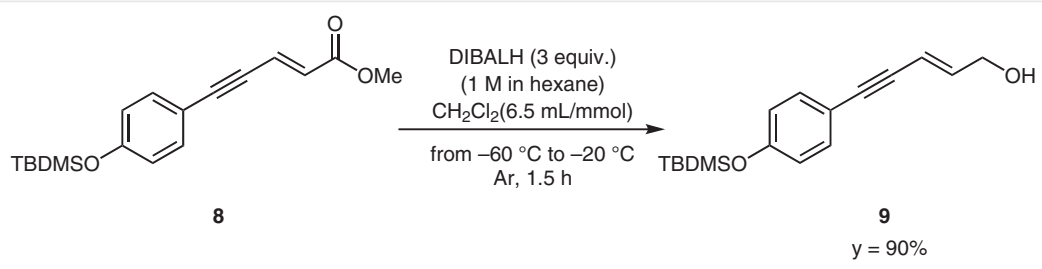

Scheme 4 Reduction of the ester moiety of $\mathbf{8}$ to form the allylic alcohol $\mathbf{9}$<smiles>COc1ccc(C#C/C=C/CO)cc1</smiles>

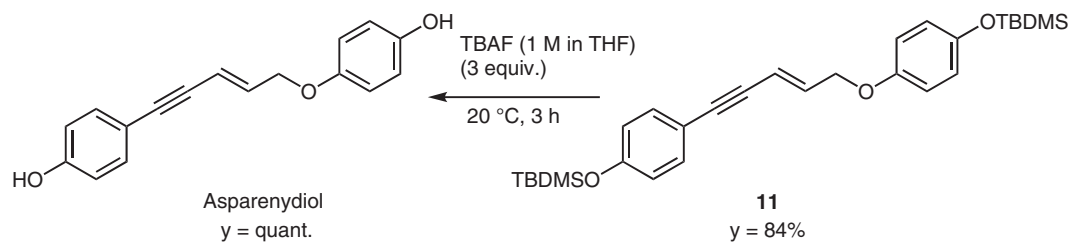

Scheme 5 Mitsunobu etherification to synthesize intermediate 11 and deprotection to form Asparenedyol (15) 
carboxylate (DEAD) and $\mathrm{PPh}_{3}$, as shown in Scheme 5. The reaction was monitored by TLC, and reached completion after $6 \mathrm{~h}$. The crude material was purified by flash chromatography and the intermediate $\mathbf{1 1}$ was isolated with a yield of $84 \%$. The final step involved treatment of 11 with tetran-butylammonium fluoride (TBAF), to deprotect the two hydroxyl moieties. Asparenydiol (15) was obtained and easily purified by flash chromatography and isolated in quantitative yield.

In conclusion, the total synthesis of Asparenydiol (15) was accomplished with an overall yield of 30\%, starting from 4-iodophenol, through two Sonogashira crosscoupling reactions catalyzed by supported catalysts and a Mitsunobu etherification (Scheme 6). Therefore, this work will make possible an extensive screening of its pharmacological activities. Moreover, it was an interesting application of our supported Pd and Cu catalysts, which allowed, in this case, higher conversions and yield, with respect to most common commercially available supported catalysts.

When not otherwise specified, all reactions were performed under argon atmosphere; solvents and reagents were handled using hypodermic syringes conveniently stored in a desiccator. Commercial re- agents were directly used without further purification. Dichloromethane and triethylamine were dried over calcium hydride and distilled, whereas hexane and toluene were dried respectively over $\mathrm{LiAlH}_{4}$ and sodium and then distilled. When specified, solvents were purged by argon bubbling. Catalysts, $\mathrm{PdCl}_{2}\left(\mathrm{PPh}_{3}\right)_{2}$ (CAS: 13965-03-2), $\mathrm{PdCl}_{2}\left(\mathrm{PPh}_{3}\right)_{2} / \mathrm{PS}$ (Pd: $\left.1.01 \mathrm{mmol} / \mathrm{g}\right)$, FibreCat 1007 (Pd: 0.72 $\mathrm{mmol} / \mathrm{g}$ ), and Pd En Cat ${ }^{\mathrm{TM}} 40$ (Pd: $0.42 \mathrm{mmol} / \mathrm{g}$ ) where purchased from Merck-Sigma-Aldrich. 4-Iodophenol (CAS: 540-38-5), tert-butyldimethylsilylchloride (TBDMSCl; CAS: 18162-48-6), pyrrolidine (CAS: 123-75-1), $\mathrm{AgNO}_{3}$ (CAS: 7761-88-8), pyridine (CAS: 110-86-1), propiolic acid (CAS: 471-25-0), diethyl 1,2-hydrazinedicarboxylate (ca. 40\% in toluene; CAS: 1972-28-7), triphenylphosphine (CAS: 60335-0), and tetrabutylammonium fluoride (1 M in THF; CAS: 429-414) were purchased by Merck-Sigma-Aldrich and used without further purification. Reactions were followed by GC and GC/EI-MS on small reaction samples. Purification of the crude reaction mixtures were performed by flash chromatography using Silica Gel 60 (40-63 $\mu \mathrm{m}$, Merck-Sigma-Aldrich), or by fractional distillation. TLC silica gel plates were purchased from Merck (Merck 60 F254). Gas chromatography (GC) analyses were performed with a Dani GC 1000 with PTV injector, FID detector and two bonded FSOT columns (Alltech, $30 \mathrm{~m}$ $0.25 \mathrm{~mm}$ i.d., $0.25 \mathrm{~mm}$ ): AT-5 (column 1) and AT-35 (column 2). Gas chromatography mass spectrometry (GC/MS) analyses were performed with an Agilent apparatus: mass selective detector 5973 Network, $6890 \mathrm{~N}$ Network GC system and HP-5MS bonded column (30 m $0.25 \mathrm{~mm}$ i.d., $0.25 \mathrm{~mm}$, column 3). NMR spectra were recorded with Bruker $400 \mathrm{MHz}$, Bruker Avance II DRX 400, or Varian INOVA $600 \mathrm{MHz}$

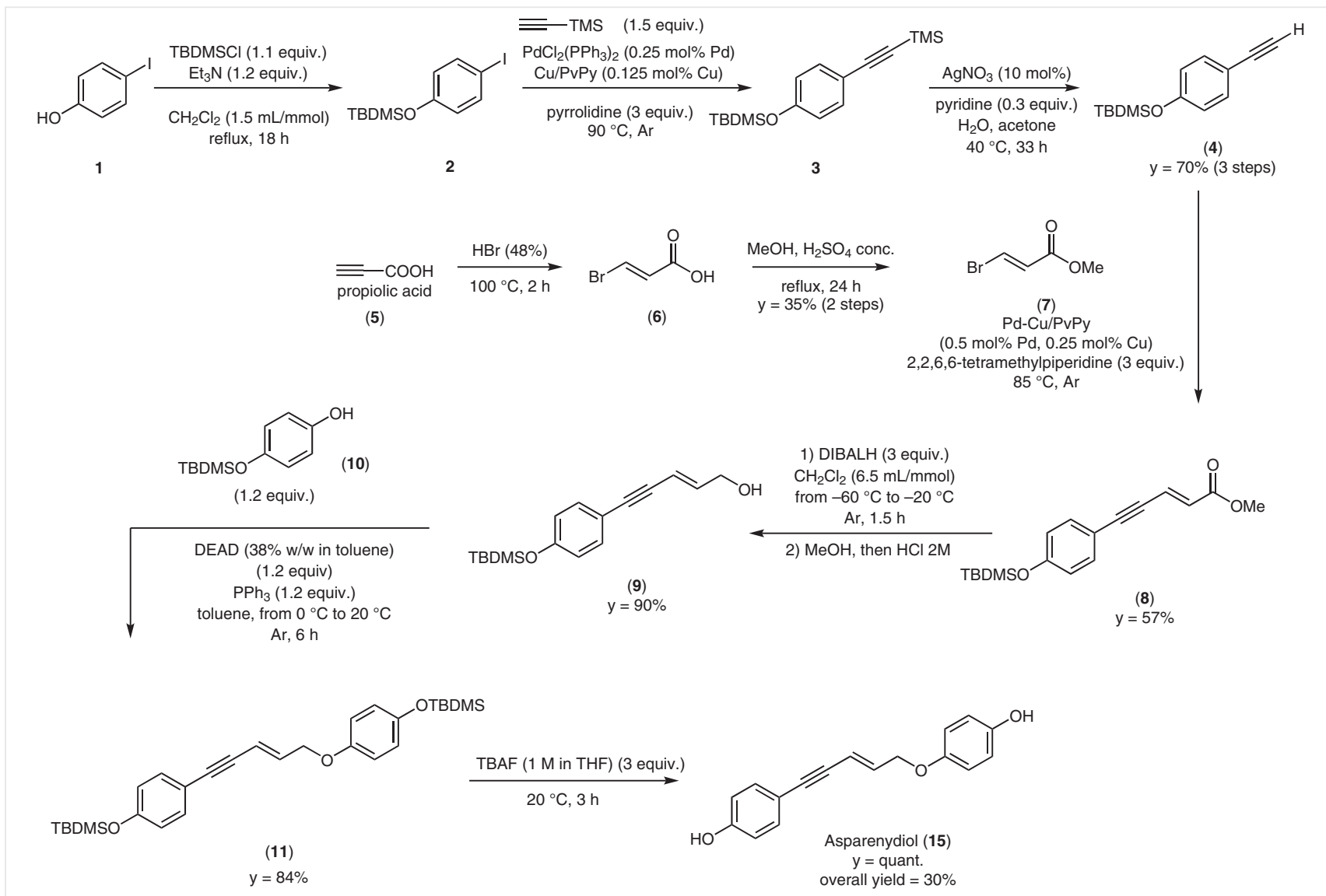

Scheme 6 Optimized total synthesis of Asparenydiol 
spectrometers. HPLC-ESI-Q/ToF flow injection analyses (FIA) were carried out with a 1200 Infinity HPLC (Agilent Technologies, USA), coupled with a quadrupole-time of flight tandem mass spectrometer (6530 Infinity Q-TOF; Agilent Technologies) through a Jet Stream ESI interface (Agilent). Mass Hunter Workstation Software (B.04.00) was used to control the HPLC and the mass spectrometer, for data acquisition, and for data analysis.

\section{tert-Butyldimethylsilyloxy-4-iodobenzene (2)}

In a $250 \mathrm{~mL}$ two-necked, round-bottom flask, equipped with a reflux condenser, under an inert atmosphere, 4-iodophenol (1; 6.6 g, 30.0 mmol) was dissolved in anhydrous $\mathrm{CH}_{2} \mathrm{Cl}_{2}(40 \mathrm{~mL})$. Freshly distilled triethylamine $(5.00 \mathrm{~mL}, 36.0 \mathrm{mmol})$ and TBDMSCl $(5.00 \mathrm{~g}, 33.0 \mathrm{mmol})$ were added to the solution, and the mixture was stirred at reflux temperature for $22 \mathrm{~h}$. The reaction was quenched with $\mathrm{HCl} 2 \mathrm{M}$ and extracted with $\mathrm{CH}_{2} \mathrm{Cl}_{2}(3 \times 30 \mathrm{~mL})$. The combined organic phases were washed with a saturated solution of $\mathrm{NaHCO}_{3}$ and a saturated solution of $\mathrm{NaCl}$ until neutrality was reached. The solution was dried over $\mathrm{Na}_{2} \mathrm{SO}_{4}$, filtered and concentrated under reduced pressure. The product was obtained as a yellow oil ( $9.36 \mathrm{~g}$ ) with a yield of $93 \%$ and a GC purity $>98 \%$. The intermediate was used without further purification for the next steps. Spectroscopic data were consistent with reported values. ${ }^{25}$

${ }^{1} \mathrm{H} \mathrm{NMR}\left(\mathrm{CDCl}_{3}, 600 \mathrm{MHz}\right): \delta=7.5(\mathrm{dd}, J=6.8,2.1 \mathrm{~Hz}, 2 \mathrm{H}), 6.6(\mathrm{dd}, J=$ 6.6, $2.1 \mathrm{~Hz}, 2 \mathrm{H}), 0.9(\mathrm{~s}, 9 \mathrm{H}), 0.18(\mathrm{~s}, 6 \mathrm{H})$.

MS (EI): $m / z(\%)=335(8), 334[\mathrm{M}]^{+}(44), 279$ (7), 278 (34), 277 (100), 151 (8), 150 (49), 149 (6), 135 (34).

\section{4-tert-Butyldimethylsilyloxyphenylethynyltrimethylsilane (3)}

In a $5 \mathrm{~mL}$ Schlenk flask, equipped with a two-neck connection, with a reflux condenser, under an inert atmosphere, $\mathrm{Pd}$ and $\mathrm{Cu}$ catalysts were added in the amounts indicated in Table 2. Pyrrolidine (300 or $500 \mu \mathrm{L}, 4.00$ or $6.00 \mathrm{mmol}), 2(0.668 \mathrm{~g}, 2.00 \mathrm{mmol})$ and trimethylsilylacetylene (13) $(415 \mu \mathrm{L}, 3.00 \mathrm{mmol})$ were added to the solution. The mixture was stirred at $90^{\circ} \mathrm{C}$ for $3.5 \mathrm{~h}$ (Table 2, entry 12 ), then the reaction was quenched with a saturated solution of $\mathrm{NH}_{4} \mathrm{Cl}$. The mixture was extracted with $\mathrm{Et}_{2} \mathrm{O}(3 \times 50 \mathrm{~mL})$ and the combined organic phases were dried over $\mathrm{Na}_{2} \mathrm{SO}_{4}$, filtered and concentrated under reduced pressure. The residue was purified by flash chromatography on silica gel (pure hexane). The product was obtained as a yellowish oil with $81 \%$ yield $(0.492 \mathrm{~g}$ ) (purity $>95 \%$ by GC). Spectroscopic data were consistent with reported values. ${ }^{14}$

${ }^{1} \mathrm{H} \mathrm{NMR}\left(\mathrm{CDCl}_{3}, 400 \mathrm{MHz}\right): \delta=7.4(\mathrm{~d}, J=8.0 \mathrm{~Hz}, 2 \mathrm{H}), 6.8(\mathrm{~d}, J=8.0 \mathrm{~Hz}$, $2 \mathrm{H}), 1.0$ (s, $9 \mathrm{H}), 0.3$ (s, $9 \mathrm{H}), 0.2$ (s, $6 \mathrm{H})$.

${ }^{13} \mathrm{CNMR}\left(\mathrm{CDCl}_{3}, 100 \mathrm{MHz}\right): \delta=156.1,133.5,130.4,120.1,116.0,105.3$, 92.6, 25.7, 18.2, 0.11, -4.4.

MS (EI): $m / z(\%)=305(10), 304\left[\mathrm{M}^{+}\right.$(34), 289 (13), 249 (12), 248 (33), 247 (100), 233 (11), 116 (8), 73 (12).

\section{4-tert-Butyldimethylsilyloxy-1-ethynylbenzene (4)}

In a $250 \mathrm{~mL}$ two-necked, round-bottom flask, equipped with a reflux condenser, under inert atmosphere, $3(3.04 \mathrm{~g}, 10.0 \mathrm{mmol})$, acetone (75 mL), pyridine $(243 \mathrm{~mL}, 0.30 \mathrm{mmol})$, and a solution of $\mathrm{AgNO}_{3}$ $(0.170 \mathrm{~g}, 1.00 \mathrm{mmol})$ in $\mathrm{H}_{2} \mathrm{O}(10.8 \mathrm{~mL})$ were stirred at $40{ }^{\circ} \mathrm{C}$ for $33 \mathrm{~h}$. The reaction was quenched with a saturated solution of $\mathrm{NaCl}$ and extracted with $\mathrm{Et}_{2} \mathrm{O}(3 \times 50 \mathrm{~mL})$. The combined organic phases were dried over $\mathrm{Na}_{2} \mathrm{SO}_{4}$, filtered and concentrated under reduced pressure. The residue was purified by flash chromatography on silica gel (pure hexane) and the product was isolated as a colorless oil with a yield of $97 \%$ ( $2.25 \mathrm{~g}$ ) (purity > 99\% by GC). Spectroscopic data were consistent with reported values. ${ }^{14}$

${ }^{1} \mathrm{H} \mathrm{NMR}\left(\mathrm{CDCl}_{3}, 400 \mathrm{MHz}\right): \delta=7.4(\mathrm{~d}, J=8.6 \mathrm{~Hz}, 2 \mathrm{H}), 6.8(\mathrm{~d}, J=8.7 \mathrm{~Hz}$, $2 \mathrm{H}), 3.0(\mathrm{~s}, 1 \mathrm{H}), 1.0(\mathrm{~s}, 9 \mathrm{H}), 0.2(\mathrm{~s}, 6 \mathrm{H})$.

${ }^{13} \mathrm{C} \mathrm{NMR}\left(\mathrm{CDCl}_{3}, 100 \mathrm{MHz}\right): \delta=156.3,133.6,127.1,120.2,114.8,83.7$, 75.9, 25.6, 18.2, -4.4 .

MS (EI): $m / z(\%)=232[\mathrm{M}]^{+}(19), 177$ (6), $176(24), 175$ (100), 159 (3), $145(5), 115(4)$.

\section{Methyl (E)-3- Bromoacrylate (7)}

In a $500 \mathrm{~mL}$ three-necked, round-bottom flask, equipped with a reflux condenser and mechanical stirrer, under an inert atmosphere, were introduced propiolic acid ( $25 \mathrm{~g}, 357 \mathrm{mmol}$ ) and $\mathrm{HBr}$ (48\% solution, $150 \mathrm{~mL}$ ). The resulting mixture was stirred at $100{ }^{\circ} \mathrm{C}$ for $2 \mathrm{~h}$. The reaction flask was cooled to r.t. and, subsequently, cooled in an ice bath to induce crystallization of (E)-3-bromoacrylic acid. The precipitate was filtered, washed with cool water and dried. The product was obtained as a crystalline white solid with a yield of $74 \%(40.3 \mathrm{~g}$ ) and identified as (E)-3-bromoacrylic acid. Spectroscopic data were consistent with reported values. ${ }^{32}$

M.p. $=117-118^{\circ} \mathrm{C}\left(\right.$ lit. $\left.^{32} 117.5-118.5^{\circ} \mathrm{C}\right)$.

${ }^{1} \mathrm{H} \mathrm{NMR}\left(\mathrm{CDCl}_{3}, 600 \mathrm{MHz}\right): \delta=11.0(\mathrm{~s}, 1 \mathrm{H}), 7.7(\mathrm{~d}, J=14.3 \mathrm{~Hz}, 1 \mathrm{H})$, $6.5(\mathrm{~d}, J=14.3 \mathrm{~Hz}, 1 \mathrm{H})$.

MS (EI): $m / z(\%)=152$ (98), 150 (100) [M], 135 (57), 133 (58), 124 (14), 107 (35), 105 (36), 71 (76), 45 (28).

In a $500 \mathrm{~mL}$ three-necked, round-bottom flask, equipped with a reflux condenser and mechanical stirrer, under an inert atmosphere, (E)-3-bromoacrylic acid $(19.2 \mathrm{~g}, 128 \mathrm{mmol}$ ) was dissolved in anhydrous $\mathrm{MeOH}\left(200 \mathrm{~mL}\right.$ ) and 15 drops of concentrated $\mathrm{H}_{2} \mathrm{SO}_{4}$ were added. The reaction mixture was stirred at reflux temperature for $24 \mathrm{~h}$. The solvent was removed through distillation under reduced pressure and the residue was poured on a saturated solution of $\mathrm{NaHCO}_{3}(50$ $\mathrm{mL})$. The mixture was extracted with $\mathrm{Et}_{2} \mathrm{O}(3 \times 50 \mathrm{~mL})$ and the combined organic phases dried over $\mathrm{Na}_{2} \mathrm{SO}_{4}$, filtered and concentrated under reduced pressure. Spectroscopic data were consistent with reported values.

B.p. $=72-75^{\circ} \mathrm{C}, 70 \mathrm{mbar}$ (lit. $\left..^{39} 69^{\circ} \mathrm{C}, 55 \mathrm{mbar}\right)$.

${ }^{1} \mathrm{H}$ NMR $\left(\mathrm{CDCl}_{3}, 600 \mathrm{MHz}\right): \delta=7.6(\mathrm{~d}, J=12.0 \mathrm{~Hz}, 1 \mathrm{H}), 6.5(\mathrm{~d}, J=$ $12.0 \mathrm{~Hz}, 1 \mathrm{H}), 3.7$ (s, $3 \mathrm{H})$.

MS (EI): $m / z(\%)=166$ (24), 164 (24), 135 (99), 133 (100), 107 (28), 105 (28), 85 (45), 54 (5), 53 (5).

\section{Methyl 5-(E)-4-tert-Butyldimethylsilyloxy-phenyl-pent-2-en-4- yn-1-ate (8)}

In a $10 \mathrm{~mL}$ Schlenk flask, equipped with a two-neck connection, with a reflux condenser, under inert atmosphere, Pd and Cu catalysts were added in the amounts indicated in Table 4. 2,2,6,6-Tetramethylpiperidine ( 1 or $2 \mathrm{~mL}, 6.00$ or $12.0 \mathrm{mmol}), 4(0.696 \mathrm{~g}, 3.00 \mathrm{mmol}$ ) and 7 $(0.330 \mathrm{~g}, 2.00 \mathrm{mmol})$ were added to the solution. In the best condition found (Table 4, entry 2) the mixture was stirred at $85^{\circ} \mathrm{C}$ for $3.5 \mathrm{~h}$ and the reaction was quenched with a saturated solution of $\mathrm{NH}_{4} \mathrm{Cl}$. The mixture was extracted with $\mathrm{Et}_{2} \mathrm{O}(3 \times 15 \mathrm{~mL})$ and the combined organic phases were dried over $\mathrm{Na}_{2} \mathrm{SO}_{4}$, filtered and concentrated under reduced pressure. The residue was purified by flash chromatography on silica gel (Hex/EtOAc, 95:5). The product was obtained as a yellowish oil with $57 \%$ yield $(0.360 \mathrm{~g})$. 
${ }^{1} \mathrm{H}$ NMR $\left(\mathrm{CDCl}_{3}, 400 \mathrm{MHz}\right): \delta=7.3(\mathrm{~d}, J=8.7 \mathrm{~Hz}, 2 \mathrm{H}), 6.9(\mathrm{~d}, J=$ $15.8 \mathrm{~Hz}, 1 \mathrm{H}), 6.8(\mathrm{~d}, J=8.7 \mathrm{~Hz}, 2 \mathrm{H}), 6.2(\mathrm{~d}, J=15.8 \mathrm{~Hz}, 1 \mathrm{H}), 3.7(\mathrm{~s}$, $3 \mathrm{H}), 0.9(\mathrm{~s}, 9 \mathrm{H}), 0.2(\mathrm{~s}, 6 \mathrm{H})$.

${ }^{13} \mathrm{C}$ NMR $\left(\mathrm{CDCl}_{3}, 100 \mathrm{MHz}\right): \delta=166.7,157.1,133.8,128.7,125.9$, $120.5,115.0,99.2,85.8,52.0,25.8,18.4,-4.4$.

MS (EI): $m / z(\%)=317(10), 316(42)[\mathrm{M}]^{+}, 285$ (8), 261 (8), 260 (30), 259 (100), 227 (8), 199 (7), 73 (6).

Anal. Calcd. for $\mathrm{C}_{18} \mathrm{H}_{24} \mathrm{~N}_{3} \mathrm{Si}$ : C 68.32, H 7.64. Found: C 68.27, H 7.61.

\section{5-(E)-4-tert-Butyldimethylsilyloxy-phenyl-pent-2-en-4-yn-1-ol}

(9)

In a $250 \mathrm{~mL}$ two-necked, round-bottom flask, under an inert atmosphere, 8 (3.16 g, $10.0 \mathrm{mmol}$ ) was dissolved in anhydrous $\mathrm{CH}_{2} \mathrm{Cl}_{2}(65$ $\mathrm{mL})$. The solution was cooled to $-60{ }^{\circ} \mathrm{C}$ and DIBALH ( $1 \mathrm{M}$ in hexane, $30 \mathrm{~mL}$ ) was slowly dropped into the well-stirring mixture. The mixture was stirred for $1.5 \mathrm{~h}$ and the temperature was allowed to warm up to $-20^{\circ} \mathrm{C}$. The reaction was quenched, at low temperature, by slowly dropping in $\mathrm{MeOH}(20 \mathrm{~mL})$, followed by $\mathrm{HCl}(1 \mathrm{M} 20 \mathrm{~mL})$ and a saturated solution of Rochelle salt $(50 \mathrm{~mL})$. The resulting mixture was extracted with $\mathrm{CH}_{2} \mathrm{Cl}_{2}(3 \times 30 \mathrm{~mL})$ and the combined organic phases were washed again with Rochelle salt $(30 \mathrm{~mL})$ and dried over $\mathrm{Na}_{2} \mathrm{SO}_{4}$, filtered and concentrated under reduced pressure. The residue was purified by flash chromatography on silica gel (Hex/EtOAc, 1:1) and the product 9 was isolated as a yellowish oil with a yield of $90 \%$ (2.59 g) (purity $>99 \%$ by GC).

${ }^{1} \mathrm{H} \mathrm{NMR}\left(\mathrm{CDCl}_{3}, 400 \mathrm{MHz}\right): \delta=7.3(\mathrm{~d}, J=8.5 \mathrm{~Hz}, 2 \mathrm{H}), 6.7(\mathrm{~m}, 2 \mathrm{H}), 6.3$ $(\mathrm{dt}, J=15.8,5.3 \mathrm{~Hz}, 1 \mathrm{H}), 5.9(\mathrm{~m}, 1 \mathrm{H}), 4.2(\mathrm{~m}, 2 \mathrm{H}), 0.9(\mathrm{~s}, 9 \mathrm{H}), 0.2(\mathrm{~s}$, $6 \mathrm{H})$.

${ }^{13} \mathrm{C}$ NMR $\left(\mathrm{CDCl}_{3}, 100 \mathrm{MHz}\right): \delta=156.0,141.0,133.0,120.2,116.0$, $110.8,90.2,86.2,63.0,25.6,18.2,-4.4$.

MS (EI): $m / z(\%)=289(11), 288(50)[\mathrm{M}]^{+}, 233(7), 232(23), 231$ (100), 229 (8), 128 (8), 75 (16), 73 (8).

Anal. Calcd. for $\mathrm{C}_{17} \mathrm{H}_{24} \mathrm{O}_{2} \mathrm{Si}$ : C 70.78, H 8.39. Found: C 70.75, H 8.41

\section{4-tert-Butyldimethylsilyloxy-1-phenol (10)}

In a $250 \mathrm{~mL}$ two-necked, round-bottom flask, under an inert atmosphere, hydroquinone $(2.20 \mathrm{~g}, 20.0 \mathrm{mmol})$ was dissolved in EtOAc $(100 \mathrm{~mL})$. Imidazole $(3.40 \mathrm{~g}, 50.0 \mathrm{mmol})$ and TBDMSCl $(3.31 \mathrm{~g}, 22.0$ $\mathrm{mmol}$ ) were added to the solution and the resulting mixture was stirred for $4 \mathrm{~h}$ at $20^{\circ} \mathrm{C}$. The reaction was quenched with a saturated solution of $\mathrm{NaCl}(50 \mathrm{~mL})$ and the mixture was extracted with EtOAc $(3 \times 30 \mathrm{~mL})$. The reunited organic phases were dried over $\mathrm{Na}_{2} \mathrm{SO}_{4}$, filtered and concentrated under reduced pressure. The residue was purified by flash chromatography on silica gel (Hex/EtOAc, 8:2) and the product 10 was isolated as a white solid with a yield of $74 \%(3.31 \mathrm{~g})$ (purity $>99 \%$ by GC). Spectroscopic data were consistent with reported data. ${ }^{36}$

${ }^{1} \mathrm{H} \mathrm{NMR}\left(\mathrm{CDCl}_{3}, 400 \mathrm{MHz}\right): \delta=6.7(\mathrm{~m}, 4 \mathrm{H}), 0.9(\mathrm{~s}, 9 \mathrm{H}), 0.1(\mathrm{~s}, 6 \mathrm{H})$.

MS (EI) $m / z(\%)=225$ (4), 224 (20) [M] $]^{+}, 169$ (6), 168 (22), 167 (100), 153 (2), 137 (3), 75 (5), 73 (3).

(E)-tert-Butyl(4-(5-(4-((tert-butyldimethylsilyl)oxy)phenoxy)pent-3-en-1-yn-1-yl)phenoxy)dimethylsilane (11)

In a $25 \mathrm{~mL}$ two-necked, round-bottom flask, under an inert atmosphere, 9 (0.576 g, $2 \mathrm{mmol})$ was dissolved in anhydrous toluene (10 $\mathrm{mL})$, then 10 (0.539 g, $2.4 \mathrm{mmol})$ and $\mathrm{PPh}_{3}(0.629 \mathrm{~g}, 2.4 \mathrm{mmol})$ were added to the solution. The mixture was cooled to $0{ }^{\circ} \mathrm{C}$ and DEAD $(38 \%$ $\mathrm{w} / \mathrm{w}$ in toluene, $1.15 \mathrm{~mL}, 2.4 \mathrm{mmol}$ ) was added. The mixture was stirred at $0{ }^{\circ} \mathrm{C}$ for $6 \mathrm{~h}$, then the reaction was quenched with a saturat- ed solution of $\mathrm{NH}_{4} \mathrm{Cl}(15 \mathrm{~mL})$, and extracted with $\mathrm{CH}_{2} \mathrm{Cl}_{2}(3 \times 10 \mathrm{~mL})$. The combined organic phases were dried over $\mathrm{Na}_{2} \mathrm{SO}_{4}$, filtered and concentrated under reduced pressure. The residue was purified by flash chromatography on silica gel (Hex/toluene, 75:25). Collected fractions containing intermediate $\mathbf{1 1}$ were concentrated under reduced pressure with a yield of $84 \%$.

${ }^{1} \mathrm{H} \mathrm{NMR}\left(\mathrm{CDCl}_{3}, 400 \mathrm{MHz}\right): \delta=7.3(\mathrm{~d}, J=8.5 \mathrm{~Hz}, 2 \mathrm{H}), 6.8(\mathrm{~m}, 8 \mathrm{H}), 6.3$ $(\mathrm{dt}, J=15.9,5.3 \mathrm{~Hz}, 1 \mathrm{H}), 6.0(\mathrm{~d}, J=15.9 \mathrm{~Hz}, 1 \mathrm{H}), 4.6(\mathrm{dd}, J=5.4$, $1.6 \mathrm{~Hz}, 2 \mathrm{H}), 1.0(\mathrm{~s}, 18 \mathrm{H}), 0.22(\mathrm{~s}, 6 \mathrm{H}), 0.19(\mathrm{~s}, 6 \mathrm{H})$.

${ }^{13} \mathrm{C}$ NMR $\left(\mathrm{CDCl}_{3}, 100 \mathrm{MHz}\right): \delta=156.0,152.9,149.7,137.2,133.0$, $120.7,120.2,116.0,115.6,112.5,90.6,86.0,68.4,25.7,25.6,18.23$, $18.19,-4.40,-4.47$.

HRMS (TOF MS ES+): $m / z[\mathrm{M}+\mathrm{Na}]^{+}$calcd for $\mathrm{C}_{29} \mathrm{H}_{42} \mathrm{O}_{3} \mathrm{Si}_{2}: 517.2565$; found: 517.2553. Analytical HPLC purity $91 \%$.

\section{Asparenedyol (15)}

A solution of $\mathbf{1 1}$ was transferred to a $25 \mathrm{~mL}$ two-necked, round-bottom flask and TBAF ( $1 \mathrm{M}$ in THF, $11 \mathrm{~mL}, 2.5$ equiv) was added. The mixture was stirred at r.t. for $2.5 \mathrm{~h}$, then the reaction was quenched with a saturated solution of $\mathrm{NH}_{4} \mathrm{Cl}(20 \mathrm{~mL})$ and the mixture was extracted with $\mathrm{CH}_{2} \mathrm{Cl}_{2}(3 \times 15 \mathrm{~mL})$. The combined organic phases were concentrated under reduced pressure, dissolved in acetone, filtered on silica and concentrated. The residue was purified by flash chromatography on silica gel $\left(\mathrm{CHCl}_{3}\right.$ /acetone, 9:1). Asparenedyol was isolated as a white solid with a yield of $84 \%(0.448 \mathrm{~g})$.

${ }^{1} \mathrm{H}$ NMR (acetone- $\left.d_{6}, 400 \mathrm{MHz}\right): \delta=8.7$ (bs, $\left.1 \mathrm{H}\right), 7.9(\mathrm{bs}, 1 \mathrm{H}), 7.3(\mathrm{~m}$, $2 \mathrm{H}), 6.8(\mathrm{~m}, 6 \mathrm{H}), 6.3(\mathrm{dt}, J=15.9,5.3 \mathrm{~Hz}, 1 \mathrm{H}), 6.1(\mathrm{dt}, J=15.9,1.7 \mathrm{~Hz}$, $1 \mathrm{H})$.

${ }^{13} \mathrm{C}$ NMR (acetone- $d_{6}, 100 \mathrm{MHz}$ ): $\delta=205.5,157.8,151.8,151.6,137.8$, $133.0,115.8,115.6,114.0,111.9,90.5,85.4,68.1$.

HRMS (TOF MS ES+): $m / z$ [M - H] $]^{-}$calcd for $\mathrm{C}_{17} \mathrm{H}_{14} \mathrm{O}_{3}$ : 265.0870; found: 265.0864 .

Analytical HPLC purity $99 \%$.

\section{Funding Information}

Financial support from the University of Pisa (PRA 2018_23) is gratefully acknowledged.

\section{Acknowledgment}

G.A. is grateful to Prof. Ilaria Degano of the Department of Chemistry and Industrial Chemistry of the University of Pisa, for HPLC-HRMS analysis.

\section{Supporting Information}

Supporting information for this article is available online at https://doi.org/10.1055/s-0039-1690852.

\section{References}

(1) Terada, K.; Honda, C.; Suwa, K.; Takeyama, S.; Oku, H.; Kamisako, W. Chem. Pharm. Bull. (Tokyo) 2011, 43, 564.

(2) Zhang, H. J.; Sydara, K.; Tan, G. T.; Ma, C.; Southavong, B.; Soejarto, D. D.; Pezzuto, J. M.; Fong, H. H. S. J. Nat. Prod. 2004, 67, 194. 
(3) Jayashree, G. V.; Kumar, K. H.; Krupashree, K.; Rachitha, P.; Khanum, F. Ind. Crops Prod. 2015, 78, 102.

(4) Dembitsky, V. M. Lipids 2006, 41, 883.

(5) Fletcher, S. Org. Chem. Front. 2015, 2, 739.

(6) Swamy, K. C. K.; Kumar, N. N. B.; Balaraman, E.; Kumar, K. V. P. P. Chem. Rev. 2009, 109, 2551.

(7) Doucet, H.; Hierso, J. C. Angew. Chem. Int. Ed. 2007, 46, 834.

(8) Chinchilla, R.; Nájera, C. Chem. Rev. 2007, 107, 874.

(9) Plenio, H. Angew. Chem. Int. Ed. 2008, 47, 6954.

(10) Krascsenicsová, K.; Kasák, P.; Putala, M.; Walla, P.; Uray, G.; Kappe, C. O. Chem. Commun. 2004, 10, 2606.

(11) Fusini, G.; Barsanti, D.; Angelici, G.; Casotti, G.; Canale, A.; Benelli, G.; Lucchi, A.; Carpita, A. Tetrahedron 2018, 74, 4381.

(12) Yin, L.; Liebscher, J. Chem. Rev. 2007, 107, 133.

(13) Garrais, S.; Turkington, J.; Goldring, W. P. D. Tetrahedron 2009, $65,8418$.

(14) Carpita, A.; Mannocci, L.; Rossi, R. Eur. J. Org. Chem. 2005, 1859.

(15) Newton, S.; Carter, C. F.; Pearson, C. M.; De C. Alves, L.; Lange, H.; Thansandote, P.; Ley, S. V. Angew. Chem. Int. Ed. 2014, 53, 4915.

(16) Sabitha, G.; Das, S. K.; Ankireddy, P.; Yadav, J. S. Tetrahedron Lett. 2013, 54, 1097.

(17) Vaz, B.; Pereira, R.; Pérez, M.; Álvarez, R.; De Lera, A. R. J. Org. Chem. 2008, 73, 6534.

(18) Hulot, C.; Blond, G.; Suffert, J. J. Am. Chem. Soc. 2008, 130, 5046.

(19) Hashmi, A. S. K.; Graf, K.; Ackermann, M.; Rominger, F. ChemCatChem 2013, 5, 1200.

(20) Takeuchi, R.; Tanabe, K.; Tanaka, S. J. Org. Chem. 2000, 65, 1558.

(21) Nishimura, T.; Araki, H.; Maeda, Y.; Uemura, S. Org. Lett. 2003, 5 , 2997.

(22) Bates, C. G.; Saejueng, P.; Venkataraman, D. Org. Lett. 2004, 6, 1441.

(23) Ranu, B. C.; Chattopadhyay, K. Org. Lett. 2007, 9, 2409.

(24) Ranu, B. C.; Adak, L.; Chattopadhyay, K. J. Org. Chem. 2008, 73, 5609.
(25) Ogawa, T.; Ohta, K.; Iijima, T.; Suzuki, T.; Ohta, S.; Endo, Y. Bioorg. Med. Chem. 2009, 17, 1109.

(26) Evangelisti, C.; Balerna, A.; Psaro, R.; Fusini, G.; Carpita, A.; Benfatto, M. ChemPhysChem 2017, 18, 1921.

(27) Balerna, A.; Evangelisti, C.; Tiozzo, C. X-ray Spectrom. 2017, 46, 82.

(28) Evangelisti, C.; Panziera, N.; Pertici, P.; Vitulli, G.; Salvadori, P.; Battocchio, C.; Polzonetti, G. J. Catal. 2009, 262, 287.

(29) Jumde, R. P.; Marelli, M.; Scotti, N.; Mandoli, A.; Psaro, R.; Evangelisti, C. J. Mol. Catal. A: Chem. 2016, 414, 55.

(30) Laudadio, G.; Fusini, G.; Casotti, G.; Evangelisti, C.; Angelici, G.; Carpita, A. J. Flow Chem. 2019, 9, 133.

(31) Biffis, A.; Centomo, P.; Del Zotto, A.; Zecca, M. Chem. Rev. 2018, $118,2249$.

(32) Weir, J. R.; Patel, B. A.; Heck, R. F. J. Org. Chem. 1980, 45, 4926.

(33) Sauerberg, P.; Bury, P. S.; Mogensen, J. P.; Deussen, H. J.; Pettersson, I.; Fleckner, J.; Nehlin, J.; Frederiksen, K. S.; Albrektsen, T.; Din, N.; Svensson, L. A.; Ynddal, L.; Wulff, E. M.; Jeppesen, L. J. Med. Chem. 2003, 46, 4883.

(34) Bellina, F.; Carpita, A.; Corradi, C.; Rossi, R. Synth. Commun. 1996, 26, 3297.

(35) Li, L.; Shen, X.; Xu, Q. H.; Yao, S. Q. Angew. Chem. Int. Ed. 2013, $52,424$.

(36) López-Pelegrín, J. A.; Wentworth, P.; Sieber, F.; Metz, W. A.; Janda, K. D. J. Org. Chem. 2000, 65, 8527.

(37) Sauerberg, P.; Mogensen, J. P.; Jeppesen, L.; Bury, P. S.; Fleckner, J.; Olsen, G. S.; Jeppesen, C. B.; Wulff, E. M.; Pihera, P.; Havranek, M.; Polivka, Z.; Pettersson, I. Bioorg. Med. Chem. Lett. 2007, 17, 3198.

(38) Kiuchi, H.; Takahashi, D.; Funaki, K.; Sato, T.; Oi, S. Org. Lett. 2012, 14, 4502.

(39) Rossi, R.; Carpita, A.; Lippolis, V.; Benetti, M. Gazz. Chim. Ital. 1990, 120, 783. 